Again, it may be desirable that conditions in a selected series of valleys or sand rivers should, both before and after treatment, be kept under continuous physical and chemical study.

The report is a most welcome production; one would be happier about its general circulation if a shorter version of the whole were available, some. what along the lines of the author's paper "The Water Resources of Central Africa" in a recent number of the Geographical Journal. The conclusions and decisions of the Colonial Governments and the Colonial Office concerning its implementation will be awaited with the liveliest interest in many lands.

2ie

W. D. BRIND

\section{REFORM OF GERMAN HIGHER EDUCATION IN THE BRITISH ZONE OF OCCUPATION}

$\mathrm{T}$ HE Commission set up in the spring of 1948 by the British Military Governor, Sir Brian Robertson, through his edpucational adviser, Mr. Robert Birley, to expminenthe problem of the reform of the German unfreroies and technical high schools in the British 26 he of Occupation, has published its report The membership of the Commission, under troy ch $f$ irmanship of Dr. H. Everling, director of the ferman Co-operative Society, rested on a wide balis of pedagogic, social and intellectual representation; and in addition to the ten German members, the Commission included Lord Lindsay and Prof. J. R. de Salis as non-German members. The member representing the scientific disciplines was Prof. C. F. von Weizsäcker, of Göttingen.

The Commission had complete freedom of action and of expression, and it has produced a correspondingly valuable report, with a long and carefully formulated list of practical recommendations. The keynote of the report is the definition given of what, in the unanimous opinion of the Commission, the goal of higher education should be, namely, "The teaching of truth in the service of the people, of truth won always through a scientific investigation of the facts"; and the report emphasizes that the three operative words in this definition are: the people, investigation and teaching.

Four chief recommendations follow on the practical level : (1) greatly increased facilities for study for students of limited means; (2) promotion of a more intimate contact between the universities and technical high schools and all classes of society (as also the Ministries of Education) through two new advisory or administrative bodies, the 'Hochschulbeirat' and the 'Hochschulrat'; (3) an increase in the scope and in the numbers of the teaching body; (4) furtherance of education and of the unity of culture through a 'studium generale'.

These reforms, in particular (1) and (3), demand increased funds for higher education; and the Commission unanimously and explicitly stresses that the possible argument that Germany cannot afford these luxuries under present conditions is false. The report makes the point that any outlay contemplated under the reforms recommended must be a very small percentage of the total State expenditure; that on the * Gutachten zur Hochschulreform. Pp. v+132.
Studienausschuss fur Hochschulreform, Besenbinderhof 52, 1948.) most mundane level one has to recognize that the fundamental discovery of to-day is the technical application of to-morrow ; that, however, the scientific investigation of facts is a unified discipline; and, finally, that any one branch of scientific investigation must wither if the whole tree of knowledge is not, healthy.

The report devotes special chapters to the four chief recommendations listed above.

(1) Even allowing for the working-class fear, explicitly admitted in the report, that students from the working-class, once having entered a bourgeois university, might desert their class rather than in fluence their new environment, nevertheless the Commission is unanimous in insisting on the desirability of the entry to higher education being made dependent on merit and capability alone, and not on means. Further, the importance for students of making practical contact with life within their chosen profession, while still in statu pupillari, is stressed, not only in the scientific and technical faculties, but also everywhere where a student in the latter end must have contact with the people, be he pastor, lawyer, economist or medical practitioner. Here the Commission recognizes the danger that faces German scholarship in particular of an unsymmetrical absorption in theoretical principles divorced from life.

(2) It is recommended that attached to each university and technical high school in Western Germany there should be : (a) a 'Hochschulbeirat' or advisory committee, widely representative of the life of the community, meeting at least once yearly under the chairmanship of the rector; the 'Beirat' would be purely advisory, its chief aim being to maintain contact between university and public opinion; (b) a 'Hochschulrat' or administrative council, charged with the administrative affairs of the university or technical high school, opposite the Ministry of Education in the 'Land' responsible for the university in question. Each 'Rat' would have six voting members-two elected by the 'Hochschulbeirat', two by the Senate, two by the Ministry of Education-none of whom should be paid servants either of the Ministry or the university; and three non-voting members-an official of the Ministry of Education, the rector, and an elected representative of the teaching body. The 'Rat' would be steered by a president, appointed for life by all nine members of that body.

(3) With regard to increasing the teaching body in size and scope, by far the most important recom. mendation is for the foundation in each faculty of every university of new positions carrying a purely pedagogic assignment and responsibility-'Studiendozenten' and 'Studienprofessoren'. The report admits quite freely that the Commission is recommending here a break with the Humboldt tradition of Lern- and Lehr-freiheit of the nineteenth century in the German universities - a tradition which the report nevertheless recalls with pride. These new teaching posts would carry the status and privileges of the traditional scholarly 'Dozent' and 'Professor'; but the men would be chosen for their pedagogic aptitude and enthusiasm, rather than for their eminence in a particular scholarly discipline.

(4) The recommendation of the Commission that the universities and technical high schools experiment with a 'studium generale', intensively in the first two semesters, less intensively in the third and fourth semesters, arises from the conviction expressed 
in the report that the universities have with the increase of specialization within the separate faculties become less centres of education and increasingly places of vocational training. The opinion tacitly advanced in the report is that the need for an adjustment of equilibrium towards a knowledge and appreciation of other mental disciplines is greatest among students of science and technology: explicitly, the report recommends that in the universities the humanistic-philosophical and sociologicalhistorical disciplines be thrown open through very general lecture courses to students of all faculties, a task in which the 'Studienprofessoren' and 'Studiendozenten' are expected to make their special contribution; and that in the technical high schools a completely new faculty of humanistic-sociological studies be founded. It is pointed out that this latter recommendation is in line with the findings of the Darmstadt Congress in 1947 on the Education of Engineers, at which the most lively appreciation of the 'dæmonic power' of technology divorced from social awareness was widely expressed.

RONALD FraSER

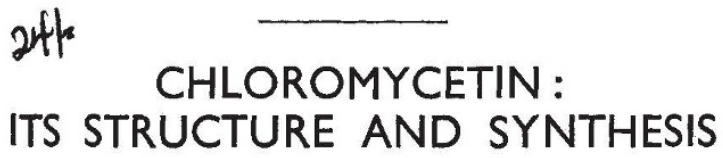

By PROF. H. RAISTRICK, F.R.S.

$\mathrm{C}$ HLOROMYCETIN, now also known as chloramphenicol, is an antibiotic which was first described by members of the research staff of Parke, Davis and Company, Detroit, Michigan, U.S.A.1,2. It is a metabolic product of a new species of Streptomyces, $S$. venezuelce, n.sp., isolated from soil orig. inating near Caracas, Venezuela, and is present in the filtrate from submerged aerated cultures of this micro-organism.

The antibiotic was isolated from the culture filtrate by solvent extraction and was finally obtained as colourless or light yellow needles or plates, m.p. $149 \cdot 7-150 \cdot 7^{\circ}$. In vitro tests ${ }^{1,3}$ showed that it is active against a number of Gram-positive and, significantly, also against many Gram-negative bacteria. J. E. Smadel and E. B. Jackson ${ }^{4,5}$ showed that chloromycetin is highly active in tests on chick embryos and mice experimentally infected with a number of rickettsiæ and viruses, including rickettsial pox and the viruses of psittacosis and lympho. granuloma venereum.

Clinical trials of chloromycetin in human patients have given most promising results. Twenty-five proved cases of scrub typhus were treated with chloromycetin at Kuala Lumpur, Malaya ${ }^{6}$. Twelve comparable cases served as controls. In the treated patients there was a remarkable response, there being no deaths and no complications. In the control patients, one died and two had complications.

Twenty-two cases of epidemic, louse-borne typhus were treated during an epidemic of this disease in the Department of La Paz, Bolivia, during late 1947 ?. Fifty untreated cases of typhus, of whom fourteen died, occurring in the same epidemic, served as controls. The favourable effect of treatment with chloromycetin appeared rapidly and the patient usually entered convalescence within three days. All of them made a rapid recovery.

Until a few days ago, very little had been published on the chemistry of chloromycetin. It was known ${ }^{1,2}$ that chloromycetin contains carbon, hydrogen, oxygen, nitrogen and non-ionic chlorine. But although analyses of the substance were published ${ }^{1,2}$, no empirical formula was assigned to it. Then, in the issue of The Times of March 28, there appeared a short communication entitled "Artificial Production of Chloromycetin" from its New York correspondent. This article contained the following statement which must have made many a biochemist who read it feel considerable scepticism :

"In making the drug chemically research scientists found for the first time a natural compound containing a nitro-benzene grouping that has always been thought harmful to animal life. Now it was found to be harmless as part of the antibiotic. They found also that the drug was a derivative of dichloracetic acid, another chemical never before found in a natural product."

The second part of the statement is not particularly surprising since a number of mould metabolic products are known which contain non-ionic chlorine, and one of them, caldariomycin ${ }^{8}, \mathrm{C}_{5} \mathrm{H}_{8} \mathrm{O}_{2} \mathrm{Cl}_{2}$, which is almost certainly $2: 2$-dichlorocyclopentane-1:3diol, contains the grouping $-\mathrm{CCl}_{2}-\mathrm{CHOH}-$, which is not unrelated to dichloracetic acid. The presence of a nitro-benzene grouping was so contrary to one's biochemical instincts as to appear very improbable.

All one's doubts on this point, however, were set at rest by the receipt in Britain of the abstracts of three papers on the structure and synthesis of chloromycetin by members of the research stąff of Parke, Davis and Company, headed by their director, Dr. Leon A. Sweet. These papers were read at a meeting of the Division of Medicinal Chemistry of the American Chemical Society held in San Francisco, California, on Tuesday afternoon, March 29.

In the first abstract, dealing with the structure of chloromycetin, the empirical formula $\mathrm{C}_{11} \mathrm{H}_{12} \mathrm{Cl}_{2} \mathrm{~N}_{2} \mathrm{O}_{5}$ was assigned to it, and it was shown to form a di. $O$-acetyl compound. It was further stated that "acid or alkaline hydrolysis produces a halogen-free base and a halogen-containing acid. The base contains both nitrogen atoms, one of which is present as a primary amine and the other as an aromatic nitro group".

The other two abstracts deal with two different approaches to the synthesis of chloromycetin, but too briefly and in too vague terms to describe them profitably, and no structural formula for chloromycetin was advanced in them. It has now been announced by the Parke, Davis Research Laboratories that chloromycetin has the structure shown and is described as $(l)-1-1$-paranitrophenyl-2-dichloro acetamido propane-1 : 3-diol.

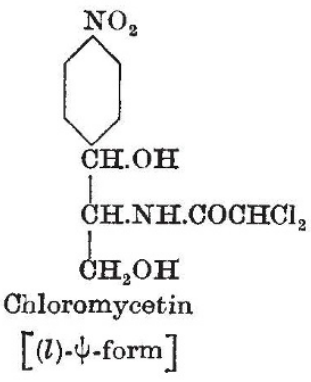

It will be seen that this structure contains two asymmetrical carbon atoms, and the authors state that one of the isomers-that described above"proved to be identical in all physical, chemical and 